\title{
Use of the copepod Oithona hebes as a bioencapsulator of essential fatty acids
}

\author{
Marcia Vanacor Barroso ${ }^{1}$, Breno Barroso Boos ${ }^{2}$, Rosemar Antoniassi ${ }^{3}$, Luiz Fernando Loureiro Fernandes ${ }^{4}$ \\ ${ }^{1}$ Instituto Capixaba de Pesquisa, Assistência Técnica e Extensão Rural - Incaper. \\ (Rodovia BR 101 Norte Km 151, Linhares, ES, CEP. 29.915-140) \\ ${ }^{2}$ Universidade do Vale do Itajaí - Univali. \\ ${ }^{3}$ Empresa Brasileira de Pesquisa Agropecuária - Embrapa. \\ ${ }^{4}$ Universidade Federal do Espírito Santo - UFES. \\ *Corresponding author: vanacor@incaper.es.gov.br
}

\section{Abstract}

The advantages of using copepods in aquaculture include nutritional superiority, high digestibility and broad spectrum of sizes, with the possibility of bioencapsulation of nutrients, probiotics and medicines. This study aimed to compare the effects of feeding copepods with a microalgae diet and two commercial inert diets on the copepod culture performance and their fatty acid profile. Wild copepods were collected in the estuarine system of Piraquê-açu River, Aracruz, Espírito Santo, Brazil, with a conical net of $60 \mathrm{~cm}$ in diameter and 200 $\mu \mathrm{m}$ mesh with a blind cup end, towed through the subsurface layer at a speed of 1 knot for 5 minutes. Once collected, the material was sieved in order to select only Oithona hebes. The experiment was conducted in nine cylindrical-conical tanks with a $60 \mathrm{~L}$ capacity, salinity of $25.8 \pm 1.3$, temperature of $25.5 \pm 0.5{ }^{\circ} \mathrm{C}$ and weak aeration, stocked with a density of 1.5 copepod $/ \mathrm{mL}$. Treatments were made in triplicate and consisted of: Treatment 1 (Control) fed with microalgae Chaetoceros gracilis and Nannochloropsis oculata (1:1) with 50,000 cells.mL ${ }^{-1}$ each; Treatment 2 with S.Parkle ${ }^{\circledR}$ INVE $\left(1\right.$ g.million $\left.{ }^{-1}\right)$; and Treatment 3 with freeze-dried spirulina (1g.million $\left.{ }^{-1}\right)$. The mean final population was compared by a Tukey test $(p<0.05)$. Results showed higher population growth for copepods treated with S.parkle, which was the only treatment that presented copepodites. S.parkle was a good source of total lipids $\left(9.54 \mathrm{~g} .100 \mathrm{~g}^{-1}\right.$ dry weight), high availability of DHA, EPA and had a good DHA:EPA:ARA ratio of 12.4:3.4:1.0. Copepods that were fed S.parkle had the highest DHA levels and a DHA:EPA:ARA ratio of 15.4:2.2:1.0. This study showed that S.parkle is a good inert food for rearing the copepod $O$. hebes, demonstrating the ability of copepods to bioencapsulate nutrients, allowing their transfer in the food chain.

Descriptors: Lipids, Hatchery, Copepod, Diet.

\section{Resumo}

As vantagens do uso dos copépodos em aquicultura incluem a superioridade nutricional, alta digestibilidade e um amplo espectro de tamanhos, com a possibilidade de bioencapsular nutrientes, probióticos e medicamentos. $\mathrm{O}$ objetivo deste estudo foi comparar o efeito da alimentação de copépodos com uma dieta de microalgas e duas dietas inertes comerciais na performance de cultivo e seu perfil de ácidos graxos. Copépodos selvagens foram coletados no sistema estuarino do Rio Piraquê-açu, Aracruz, Espírito Santo, Brasil, através de arrastos com uma rede de plâncton cônica com $60 \mathrm{~cm}$ de diâmetro e malha de $200 \mu \mathrm{m}$ de abertura, com copo cego, em arrasto de subsuperfície, com velocidade de 1 nó durante 5 minutos. Após coletado, o material foi peneirado para selecionar apenas Oithona hebes. O experimento foi conduzido em nove tanques cilíndrico-cônicos com capacidade para $60 \mathrm{~L}$, salinidade de $25,8 \pm 1,3$, temperatura de 25,5 $\pm 0,5^{\circ} \mathrm{C}$, aeração fraca e povoados com uma densidade de 1,5 copépodos $/ \mathrm{mL}$. Foram realizados três tratamentos em triplicata: Tratamento 1 (Controle), alimentação com microalgas Chaetoceros gracilis e Nannochloropsis oculata (1:1) na proporção de 50.000 células $/ \mathrm{mL}^{-1}$ cada; Tratamento 2, com S.parkle ${ }^{\circledR}$ INVE (1g/milhão-1) e Tratamento 3, com spirulina liofilizada $\left(1 \mathrm{~g} /\right.$ milhão $\left.^{-1}\right)$. As médias da população final foram comparadas pelo teste de Tukey $(p<0,05)$. Os resultados demonstraram maior crescimento populacional para os copépodos com o tratamento S.parkle, sendo o único tratamento que apresentou copepoditos. O alimento S.parkle forneceu uma boa fonte de lipídios totais $\left(9.54 \mathrm{~g} .100 \mathrm{~g}^{-1}\right.$ peso seco), alta disponibilidade de DHA, EPA e uma boa proporção DHA:EPA:ARA de 12,4:3,4:1,0. Copépodos que foram alimentados com S.parkle tiveram os maiores teores de DHA e relação DHA:EPA:ARA de 15,4:2,2:1,0. Este estudo conclui que S.parkle é um bom alimento inerte para cultivo de $O$. hebes, demonstrando a habilidade dos copépodos de bioencapsular nutrientes, possibilitando sua transferência na cadeia trófica.

Descritores: Lipídios, Larvicultura, Copepodo, Dieta. 


\section{INTRODUCTION}

Copepods are a major natural food source for marine fish larvae. They are a better live food in aquaculture than rotifers and Artemia sp., normally used in intensive marine fish hatcheries, whose production techniques have already been mastered (LAVENS and SORGELOOS, 1996). The advantages of copepods are mainly due to their high nutritional value, wide range of sizes and jerky (i.e. zigzag), swimming motion, providing a visual stimulus for the larvae of pelagic fish, as they are recognized visually by the predator (VU et al., 2014; RAJKUMAR and VASAGAM, 2006; SCHIPP et al., 1999; STØTTRUP and NORSKER, 1997).

Nutritional qualities of copepods include high levels of protein and a rich source of essential fatty acids, especially highly unsaturated fatty acids (HUFAs) such as docosahexaenoic acid (DHA, 22:6 n-3) and eicosapentaenoic acid (EPA, 20:5 n-3) (STØTTRUP et al., 1999; SARGENT et al., 1999a). The DHA, EPA and arachidonic acid (ARA), the last in smaller amounts, are essential in the diet of marine fish larvae as they usually lack the elongase and desaturase enzymes. These enzymes convert dietary fatty acids such as 18:3 n-3 and 18:2 n-6 into their corresponding long-chain essential fatty acid (EFA) end products (NANTON and CASTELL, 1999; IZQUIERDO et al., 2000). These HUFAs are considered to be of great importance during the larval stages of marine fish, helping with the metamorphosis when drastic morphophysiological changes occur (SARGENT et al., 1999b; COPEMAN et al., 2002; BARROSO et al., 2013). Copepods also have a higher proportion of polar or structural lipids, which are more biologically available to fish larvae, unlike emulsions for the enrichment of rotifers and Artemia sp., which are mostly composed of triacylglycerols (three fatty acids attached to a glycerol molecule) (SORGELOOS et al., 2001; SCHIPP, 2006). Finally, copepods are a good source of antioxidants, astaxanthin, vitamins $\mathrm{C}$ and $\mathrm{E}$, and the nauplii are easily digested (SCHIPP, 2006; HERNÁNDEZ MOLEJÓN and ALVAREZ-LAJONCHÈRE, 2003; IZQUIERDO et al., 2000; STØTTRUP et al., 1999; SCHIPP et al., 1999).

Studies on copepod rearing normally use a microalgae diet, with a mix of microalgae usually showing better results than a monoalgal diet, but it is still very restricted due to its high cost and labor-intensive requirements (VU et al., 2014; KNUCKEY et al., 2005; HERNÁNDEZ MOLEJÓN and ALVAREZ-LAJONCHÈRE, 2003; LAVENS and SORGELOOS, 1996; NANTON and CASTELL, 1999). Moreover, copepods not only are the dominant group of mesozooplankton in nature, but also play a key role in the food web as they form a link between primary producers and secondary consumers, transmitting important nutrients for predators (EL-SABAAWI et al., 2009; TURNER, 2004).

The main objective of this study is to compare the effects on the copepod rearing performance and fatty acid profiles when fed with a microalgae diet and two commercial inert diets.

\section{MATERIAL AND METHODS}

Wild copepods were collected in the Piraquê-açu River estuary, Aracruz, Espírito Santo, Brazil, with a conical net of $60 \mathrm{~cm}$ in diameter and $200 \mu \mathrm{m}$ mesh fitted with a blind cup end towed through the subsurface layer at a speed of 1 knot for 5 minutes. Once collected, the material was sieved through a $710 \mu \mathrm{m}$ and a $500 \mu \mathrm{m}$ mesh to exclude undesirable individuals, and sequentially with $250 \mu \mathrm{m}$ and $200 \mu \mathrm{m}$ meshes to select Oithona hebes.

The experiment was carried out over ten days in nine 60L cylindrical-conical tanks, in order to test different copepod feeding diets. The initial stock density was 30,000 individuals (1.5 copepod $/ \mathrm{mL}$ ), salinity of $25.8 \pm 1.3$, temperature of 25.5 $\pm 0.5{ }^{\circ} \mathrm{C}$, with weak aeration and water exchange of $10 \%$. day $^{-1}$. The treatments were made in triplicate and consisted of: Treatment 1 (Control) fed with microalgae Chaetoceros gracilis and Nannochloropsis oculata at a density of 50,000 cells.mL ${ }^{-1}$ each (1:1); Treatment 2 with S.parkle ${ }^{\circledR}$ INVE (1g.million $\left.{ }^{-1}\right)$; and Treatment 3 with freeze-dried spirulina Arthrospira platensis (1g.million ${ }^{-1}$ ).

The copepod population was monitored every morning when adults, egg-bearing females, nauplii and copepodites were evaluated qualitatively and quantitatively under a stereoscopic microscope. The results of the different treatments were then compared.

After 10 days, copepods from the different treatments were sampled for biochemical analysis. Copepods were stored in sealed glass tubes at $-80^{\circ} \mathrm{C}$. Analyses were performed at the Laboratory of Fats and Oils at Embrapa Food Technology, Rio de Janeiro. Fatty Acid Methyl Esters (FAME) were obtained by direct extraction and methylation in accordance with O'FALLON et al. (2007) with a slight modification, i.e., lipids were extracted with potassion Hydroxide $(0.5 \mathrm{M})$ in methanol and incubated at $70{ }^{\circ} \mathrm{C}$ for one hour with occasional agitation to hydrolyze the sample. The methylation step was performed in accordance with HARTMAN and LAGO (1973). The FAME were obtained by the addition of ethyl ether followed by hexan, mixed by vortex. 
For the samples of S.parkle and spirulina, the extraction of lipids was carried out in accordance with the AOAC official Method 996.06, with C23 triglyceride as internal standard, and lipid contents were expressed by the weight of the dried material.

Gas chromatography (GC) was performed using an Agilent 7890 chromatograph fitted with a cianopropylsiloxane capillary column $(60 \mathrm{~m} \times 0.32 \mathrm{~mm} \times 0.25 \mathrm{~mm})$. The components were identified by comparing their retention times with those of the manufacturer's standards ( $\mathrm{Nu}-\mathrm{Chek}$ Prep $^{\circledR}$ Inc., Elysian, USA) and the standard marine-source PUFA and PUFA 3 Menhaden oil (Supelco ${ }^{\circledR}$, Bellefonte, USA). Results of FAME were expressed as weight percentage (area normalization) of the fatty acid of the total fatty acids. The standard deviation of S.parkle treatment could not be calculated due to the loss of a vial of one replicate and to the limited amount of material. However, they matched the fatty acids analyzed in other studies which also used copepods.

Analysis of variance (ANOVA) was performed to evaluate the development of the copepod population (adults, egg-bearing females and nauplii), after confirmation of the homoscedasticity of variances and normality of data distribution. The mean and standard deviation were given to each variable. When significant differences between treatments $(\alpha=0.05)$ were detected, the Tukey HSD test was applied to separate means.

As the homoscedasticity was not confirmed for the copepodites, the non-parametric Kruskal Wallis test was used. All tests were performed using STATISTICA version 6.0.

\section{RESULTS}

Oithona hebes treatment 2 was not significantly different from the others (Fig. 1), but it was the only treatment that presented copepodites at the end of the experiment, which was considered a good biological indicator. The other rearing parameters (quantity of egg-bearing females, nauplii and copepodites) evaluated did not differ statistically.

The fatty acid profile of $O$. hebes in the different treatments was divided into saturated (SFA), monounsaturated (MUFA) and polyunsaturated (PUFA) fatty acids as presented in Table 1 .

The $O$. hebes from microalgae and freeze-dried spirulina treatments had higher amounts of SFA (means of $60.33 \mathrm{~g} .100 \mathrm{~g}^{-1}$ and 65.57 g. $100 \mathrm{~g}^{-1}$, respectively) than the S.parkle treatment (48.87 g.100 $\mathrm{g}^{-1}$ ) (Table 1). The freeze-dried spirulina food

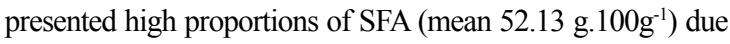
to the large amounts of palmitic acid (16:0), which presented

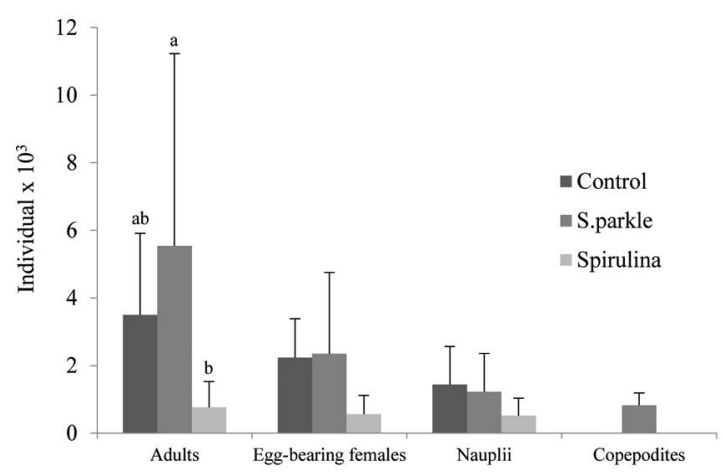

Figure 1. Final population of Oithona hebes reared with different diets.

an average of $47.74 \mathrm{~g} \cdot 100 \mathrm{~g}^{-1}$. The proportions of MUFA were closely similar in all treatments $\left(<24.0 \mathrm{~g} .100 \mathrm{~g}^{-1}\right)$.

PUFA were higher in copepods that were fed with S.parkle $\left(27.9\right.$ g. $\left.100 \mathrm{~g}^{-1}\right)$, which also had high availability of DHA (19.2 g. $\left.100 \mathrm{~g}^{-1}\right)$ and a DHA:EPA:ARA ratio of 15.4:2.2:1.0. The S.parkle diet had high availability of PUFA and a DHA:EPA:ARA ratio of 12.4:3.4:1.0. This quantity was concentrated as HUFAs, unlike the freeze-dried spirulina food that also had high amounts of PUFA (34.87 g. $\left.100 \mathrm{~g}^{-1}\right)$, but mainly composed of linoleic acid (18:2 n-6) and gamma linolenic acid (18:3 n-6), both belonging to the $n-6$ series.

The total $\mathrm{n}-6$ was similar for copepods in all treatments

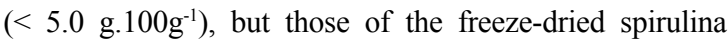
treatment were lower in ARA $\left(0.44\right.$ g. $\left.100 \mathrm{~g}^{-1}\right)$. The total $\mathrm{n}-3$ was in higher proportion in copepods from the S.parkle treatment $\left(23.43\right.$ g. $\left.100 \mathrm{~g}^{-1}\right)$. The unsaturated-saturated ratio was lower than 1.0 for copepods fed microalgae and freeze-dried spirulina treatments ( 0.7 and 0.5 , respectively)

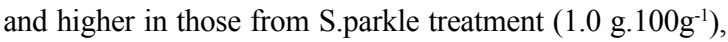
which presented n-3/n- 6 ratio of 5.2 (Table 1 ).

$O$. hebes from the freeze-dried spirulina treatment

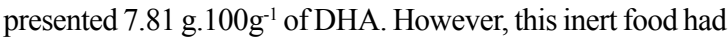
no detected DHA, and the ratio DHA/EPA of this treatment was 8.4 , as a function of very low values for EPA, presenting a disproportionate ratio between these fatty acids.

Comparatively, as shown in Table 1, O. hebes from the S.parkle treatment had a DHA/EPA ratio of 6.8 ; and the S.parkle food, 2.9. The EPA/ARA ratio was near to 2.0 for all tested copepods in all food regimes, but for the S.parkle food, this ratio was 4.3 , better for marine organisms. In relation to total lipids, the S.parkle food showed more than twice as many $\left(9.54\right.$ g. $100 \mathrm{~g}^{-1}$ dry weight) lipids than did freeze-dried spirulina food (4.21 g.100 $\mathrm{g}^{-1}$ dry weight), and greater availability of fatty acids in high demand by such marine life as HUFAs (Fig. 2). 
Table 1. Fatty acids profile (mean \pm standard deviation) of Oithona hebes in the different treatments. Values are in $g$ fatty acid. $100 \mathrm{~g}^{-1}$ total fatty acids.

\begin{tabular}{|c|c|c|c|c|c|}
\hline Fatty acids & Microalgae & Freeze-dried spirulina & S.parkle & $\begin{array}{l}\text { S.parkle } \\
\text { Food }\end{array}$ & $\begin{array}{c}\text { Freeze-dried spirulina } \\
\text { Food }\end{array}$ \\
\hline C16:0 & $30.27 \pm 5.46$ & $35.35 \pm 0.94$ & 22.22 & $20.91 \pm 0.04$ & $47.74 \pm 0.38$ \\
\hline C18:0 & $19.20 \pm 1.57$ & $16.22 \pm 3.55$ & 13.34 & $7.76 \pm 0.05$ & $1.53 \pm 0.00$ \\
\hline$\sum$ Saturated $^{\mathrm{a}}$ & $60.33 \pm 3.58$ & $65.67 \pm 4.79$ & 48.87 & $32.30 \pm 0.29$ & $52.13 \pm 0.47$ \\
\hline C16:1(n-7) & $1.86 \pm 0.56$ & $2.54 \pm 0.02$ & 2.42 & $13.45 \pm 0.09$ & $5.49 \pm 0.05$ \\
\hline C18:1(n-9) & $1.61 \pm 0.62$ & $1.70 \pm 0.02$ & 0.00 & $25.03 \pm 0.17$ & $2.99 \pm 0.05$ \\
\hline$\sum$ Monounsaturated $^{\mathrm{b}}$ & $23.87 \pm 6.78$ & $20.01 \pm 0.11$ & 23.24 & $42.85 \pm 0.17$ & $9.82 \pm 0.15$ \\
\hline C18:2(n-6) & $2.17 \pm 0.57$ & $4.41 \pm 0.82$ & 3.23 & $7.33 \pm 0.08$ & $18.76 \pm 0.09$ \\
\hline C18:3(n-6) & 0.00 & 0.00 & 0.00 & 0.00 & $15.40 \pm 0.43$ \\
\hline C20:4(n-6) ARA & $2.64 \pm 1.14$ & $0.44 \pm 0.00$ & 1.25 & $0.79 \pm 0.00$ & $0.49 \pm 0.10$ \\
\hline $\mathrm{C} 18: 3(\mathrm{n}-3)$ & 0 & 0 & 0 & $0.90 \pm 0.01$ & 0.00 \\
\hline C20:5(n-3) EPA & $4.81 \pm 2.64$ & $0.93 \pm 0.00$ & 2.83 & $3.40 \pm 0.02$ & 0.00 \\
\hline C22:6(n-3) DHA & $6.14 \pm 2.44$ & $7.81 \pm 2.74$ & 19.22 & $9.68 \pm 0.06$ & 0.00 \\
\hline$\sum$ Polyunsaturated $^{\mathrm{c}}$ & $14.59 \pm 8.29$ & $13.10 \pm 3.16$ & 27.91 & $23.32 \pm 0.15$ & $34.87 \pm 0.54$ \\
\hline$\sum$ Trans $^{\mathrm{d}}$ & $4.90 \pm 2.07$ & $3.84 \pm 0.81$ & 3.32 & $1.41 \pm 0.05$ & $2.17 \pm 0.03$ \\
\hline Total of $n-6$ & $4.15 \pm 1.14$ & $4.63 \pm 0.51$ & 4.48 & $8.12 \pm 0.08$ & $34.65 \pm 0.54$ \\
\hline Total of $n-3$ & $10.44 \pm 7.28$ & $8.47 \pm 3.67$ & 23.43 & $14.73 \pm 0.09$ & 0,0 \\
\hline$n-3 / n-6$ & 2.3 & 1.8 & 5.2 & 1.8 & 0.0 \\
\hline 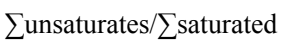 & 0.7 & 0.5 & 1.0 & 2.1 & 1.0 \\
\hline DHA/EPA & 1.3 & 8.4 & 6.8 & 2.9 & 0.0 \\
\hline EPA/ARA & 1.8 & 2.1 & 2.3 & 4.3 & 0.0 \\
\hline \multicolumn{6}{|l|}{ Total lipids } \\
\hline (g.100g-1 dry weight) & & & & 9.54 & 4.21 \\
\hline
\end{tabular}

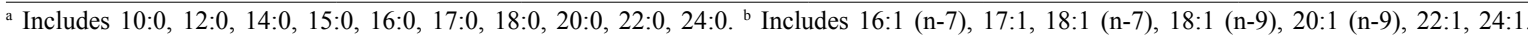
c Includes 18:2(n-6), 20:4(n-6), 18:3(n-3), 18:3(n-6), 20:5(n-3), 22:5(n-3), 22:6(n-3). ${ }^{d}$ Includes 16:1 trans, 18:1 trans, 18:2 trans. Values in each column represent two or three replicates/analysis. The unidentified peaks were not considered. S.parkle treatment without standard deviation because one sample was lost.

\section{DISCUSSION}

Among marine copepods, cyclopoids of the Oithona genus are considered the most abundant and ubiquitous copepods in the world's oceans (ALMEDA et al., 2010). Besides, they adapt to laboratory rearing, as observed for $O$. hebes in the current study, which showed good results in survival, quantity of egg-bearing females and nauplii production. These results are consistent with those found by HERNÁNDEZ MOLEJÓN and ALVAREZ-LAJONCHÈRE (2003) who worked with $O$. oculata rearing in a semicontinuous mass polyculture (density of 5-10 copepod. $\left.\mathrm{mL}^{-1}\right)$. O. hebes was shown to be a suitable (euryplastic pelagic) species, with a short life cycle and high reproductive capacity which could be fed on different food sources, especially microalgae and some artificial feed. In addition, from a biological point of view, prolificacy (abundant offspring) is an excellent biological indicator of good adaptability, as well as of physical and physiological qualities.
Results from the different diets showed that S.parkle food presented better results when used as inert food for $O$. hebes as judged by their population growth and the presence of copepodids, which occurred only in this treatment. These results corroborate those found by ALMEDA et al. (2010), who reported growth rates in $O$. davisae positively related to food concentration and temperature. The mean temperature in this experiment $\left(25.5 \pm 0.5^{\circ} \mathrm{C}\right)$ is in agreement with HERNÁNDEZ MOLEJÓN and ALVAREZ-LAJONCHÈRE (2003), showing increased feeding rates of nauplii, and, consequently, an increase in the $O$. hebes population. Nutritionally, S.parkle presented a greater amount of available lipids $\left(9.5 \mathrm{~g} .100 \mathrm{~g}^{-1}\right)$ containing a good proportion of long chain fatty acids (HUFAs), that are essential. The freeze-dried spirulina food was considered the worst quality food for copepods since it has a lower amount of total lipids ( 4.2 g. $\left.100 \mathrm{~g}^{-1}\right)$ and does not have highly unsaturated fatty acids (DHA and EPA) in the fatty acid profile. 


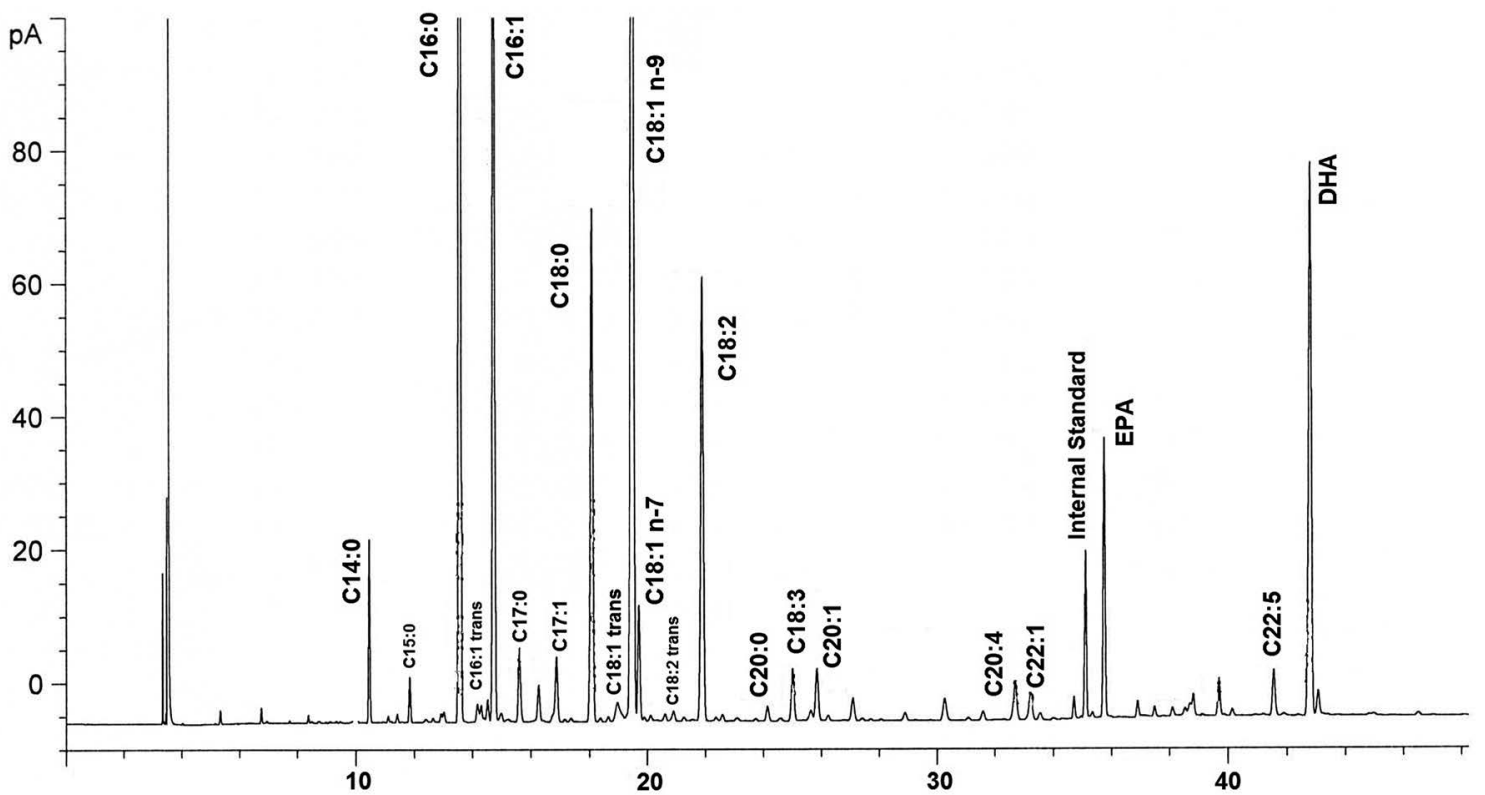

Figure 2. GC chromatogram of fatty acid methyl esters for S.parkle.

S.parkle food also has a good fatty acids ratio between DHA:EPA:ARA, similar to that of fat snook Centropomus parallelus eggs (BARROSO et al., 2013), which, according to SARGENT et al. (1999b), are the ideal nutrients for the healthy development of fish larvae. Furthermore, in the S.parkle food, a greater amount of DHA was detected. This fatty acid is necessary for maintaining the structure and functional integrity of the plasmatic membrane, due to its single conformation that allows rapid changes in the structure of lipoproteins (PLANTE et al., 2007). This study demonstrated that copepods fed with S.parkle had high availability of DHA in their tissues, differently from those observed in the copepods which ate freeze-dried spirulina. The experiment also identified the EPA in the S.parkle food and, consequently, in the copepods that were fed with it. These results corroborate the findings of NORSKER and STØTTRUP (1994), who predicted the positive correlation between the n-3 HUFA levels and the high nauplii production and those of DELBARE et al. (1996), who related the quantity of n-3 HUFA in copepods as a reflection of their ingested diet. This current study showed high nauplii and copepodite production in the S.parkle treatment, which had the highest DHA level and a good ratio between essential HUFAs.

Previous work reported by NANTON and CASTELL (1999) showed that the harpacticoid copepods Tisbe sp. and Tigropius sp. can store and maintain significant amounts of EPA and DHA when fed diets such as baker's yeast or the microalgae Dunaliella tertiolecta, which are deficient in these essential fatty acids. Supposedly, copepods do not require or need, in their metabolism, large amounts of these fatty acids, thus becoming a good source of these nutrients. DHA, EPA and ARA are components of the phospholipids in cell membranes and can act on the ion exchange and transportation, endocytosis, exocytosis and enzyme receptors. The activity of some of these membrane proteins shows that it is modulated by these lipids, which highlights the importance of these nutrients in the diet.

In the fatty acid profile of the freeze-dried spirulina food, the presence of DHA and EPA was not detected, but a high proportion of the gamma linolenic acid was defined, which, according to GUEDES et al. (2011), is an abundant fatty acid in the spirulina. On the other hand, DHA and EPA were found in tissues of the copepods fed with freeze-dried spirulina. Two explanations are possible: 1) enzymatic biosynthesis of copepods elongase $[18: 3(\mathrm{n}-6) \rightarrow 20: 3(\mathrm{n}-6) ; 20: 5(\mathrm{n}-3) \rightarrow 22: 5(\mathrm{n}-3)]$ and desaturase $[20: 3(\mathrm{n}-6) \rightarrow 20: 4(\mathrm{n}-6) \rightarrow 20: 5(\mathrm{n}-3) ; 22: 5$ $(n-3) \rightarrow 22: 6(n-3)]$ or, 2) in the absence of these fatty acids in the diet, copepods reduce their use in their metabolism and these HUFA are stored in the cell. In that case, these HUFA must have been ingested in nature. It is noteworthy that, according to GUEDES et al. (2011), the enzymatic biosynthesis of desaturase and elongase occurs with microalgae and cyanobacteria, also occurring 
with other eukaryotes, only the enzymes involved in the process varying.

To sum up, this study concludes that S.parkle is a good inert food for the rearing of the copepod $O$. hebes, as established in the zootechnical (greater population and presence of copepodids) and nutrition data, which presented greater availability of total lipids and satisfactory amount of essential fatty acids. This ability of copepods to encapsulate nutrients and transfer them in the food chain is a major advantage of their use in aquaculture.

\section{REFERENCES}

ALMEDA, R.; AUGUSTIN, C. B.; ALCARAZ, M.; CALBET, A.; SAIZ, E. Feeding rates and gross growth efficiencies of larval developmental stages of Oithona davisae (Copepoda, Cyclopoida). J. Exp. Mar. Biol. Ecol., v. 387, n. 1/2, p. 24-35, 2010.

AOAC. Official methods of analysis of the Association of Analytical Chemists. 18. ed. Gaithersburg. Maryland: AOAC, 2010.

BARROSO, M. V.; CARVALHO, C. V. A; ANTONIASSI, A; CERQUEIRA, V. R. Use of the copepod Acartia tonsa as the first live food for larvae of the fat snook Centropomus parallelus. Aquaculture, v. 388-391, p. 153-158, 2013.

COPEMAN, L. A.; PARRISH, J. A.; BROWN, C. C.; HAREL, M. Effects of docosahexaenoic, eicosapentaenoic, and arachidonic acids on the early growth, survival, lipid composition and pigmentation of yellowtail flounder (Limanda ferruginea): a live food enrichment experiment. Aquaculture, v. 210, n. 1/4, 285304, 2002.

DELBARE, D.; DHERT, P.; LAVENS, P. Zooplankton. In: LAVENS, P., SORGELOOS, P. (Eds.). Manual of the Production and Use of Live Food for Aquaculture. FAO Fish. Tech. Pap., vol. 361. Rome: FAO, 1996. p. 252-282.

EL-SABAAWI, R.; DOWER, J. F; KAINZ, M.; MAZUNDER, A. Characterizing dietary variability and trophic positions of coastal calanoid copepods: insight from stable isotopes and fatty acids. Mar. Biol., v. 156, n. 3, p. 225-237, 2009.

GUEDES, A. C.; AMARO, H. M.; BARBOSA, C. R.; PEREIRA, R. D.; MALCATA, F. X. Fatty acid composition of several wild microalgae and cyanobacteria, with a focus on eicosapentaenoic, docosahexaenoic and $\alpha$-linolenic acids for eventual dietary uses. Food. Res. Int., v. 44, p. 2721-2729, 2011.

HARTMAN, L.; LAGO, R. C. A. Rapid preparation of fatty acid methyl esters from lipids. Lab. Pract., v. 22, p. 475-494, 1973.

HERNÁNDEZ MOLEJÓN, O. G.; ALVAREZ-LAJONCHÈRE, L. Culture experiments with Oithona oculata Farran, 1913 (Copepoda: Cyclopoida), and its advantages as food for marine fish larvae. Aquaculture, v. 219, n. 1/4, p. 471-483, 2003.

IZQUIERDO, M. S.; SOCORRO, J.; ARANTZAMENDI, L.; HERNANDEZ-CRUZ, C. M. Recent advantages in lipid nutrition in fish larvae. Fish. Physiol. Biochem., v. 22, n. 2, p. 97-107, 2000.

KNUCKEY, R. M.; SEMMENS, G. L.; MAYER, R. J.; RIMMER, M. A. Development of an optimal microalgal diet for the culture of the calanoid copepod Acartia sinjiensis: effect of algal species and feed concentration on copepod development. Aquaculture, v. 249, n. 1/4, p. 339-351, 2005.
LAVENS, P.; SORGELOOS, P. Manual of the production and use of live food for aquaculture. Fisheries Technical Paper 361. Rome: Patrick Lavens and Patrick Sorgeloos, 1996. 305 p.

NANTON, D. A.; CASTELL, J. D. The effects of temperature and dietary fatty acids on the fatty acid composition of harpaticoid copepods, for use as a live food for marine fish larvae. Aquaculture, v. 175, n. 1/2, p. 167-181, 1999.

NORSKER, N. H.; STØTTRUP, J. The importance of dietary HUFAs for fecundity and HUFA content in the harpaticoid, Tisbe holothuriae Humes. Aquaculture, v. 125, n. 1/2, p. 155166, 1994.

O'FALLON, J. V.; BUSBOOM, J. R.; NELSON, M. L.; GASKINS, C. T. A direct method for fatty acid methyl ester synthesis: application to wet meat tissues, oils, and feedstuffs. J. Anim. Sci., v. 85, n 6, p. 1511-1521, 2007.

PLANTE, S.; PERNET, F.; HACHÉ, R.; RITCHIE, R.; JI, B.; MCINTOSH, D. Ontogenetic variations in lipid class and fatty acid composition of haddock larvae Melanogrammus aeglefinus in relation to changes in diet and microbial environment. Aquaculture, v. 263, p. 107-121, 2007.

RAJKUMAR, M.; VASAGAM, K. P. K. Suitability of copepod, Acartia clausi as a live feed for Seabass larvae (Lates calcarifer Bloch): compared to traditional live food organisms with special emphasis on the nutritional value. Aquaculture, v. 261 , n. 2, p. 649-658, 2006.

SARGENT, J.; BELL, G.; MCEVOY, L.; TOCHER, D.; ESTEVES, A. Recent developments in the essential fatty acid nutrition of fish. Aquaculture, v. 177, n. 1/4, p. 191-199, 1999a.

SARGENT, J.; MCEVOY, L.; ESTEVES, A.; BELL, G.; BELL, M.; HENDERSON, J.; TOCHER, D. Lipid nutrition of marine fish during early development: current status and future directions. Aquaculture, v. 179, n. 1/4, 217-229, $1999 \mathrm{~b}$.

SCHIPP, G. The use of Calanoid copepod in semi-intensive, tropical marine fish larviculture. In: CRUZ SUÁREZ, E.; MARIE, D. R.; SALAZAR, M. T.; LÓPEZ, M. G. N.; CAVAZOS, D. A. V.; CRUZ, A. C. P.; ORTEGA, A. G. (Eds.). Avances em Nutrición Acuicola VIII. Simposium Internacional de Nutrición Acuícola. Monterrey, Nuevo Leon, Mexico, 2006. p. 84-94.

SCHIPP, G. R.; BOSMANS, J. M. P.; MARSHALL, A. J. A method for hatchery culture of tropical calanoid copepods, Acartia spp. Aquaculture, v. 174, n. 1/2, p. 81-88, 1999.

SORGELOOS, P.; DHERT, P.; CANDREVA, P. Use of the brine shrimp Artemia spp., in marine fish larviculture. Aquaculture, v, 200, n. 1/2, p. 147-159, 2001.

STØTTRUP, J. G.; BELL, J. G.; SARGENT, J. R. The fate of lipids during development and cold-storage of egg in the laboratory-reared calanoid copepod, Acartia tonsa Dana, and in response to different algal diets. Aquaculture, v. 176, n. 3/4, p. 257-269, 1999.

STØTTRUP, J. G.; NORSKER, N. H. Production and use of copepods in marine fish larviculture. Aquaculture, v, 155, n. 1/4, p. 231-248, 1997.

TURNER, J. T. The importance of small planktonic copepods and their roles in pelagic marine food webs. Zool. Stud., v. 43, n. 2, p. 255-266, 2004

VU, M. T. T.; JEPSEN, P. M.; HANSEN, B. W. A comprehensive and precise quantification of the calanoid copepod Acartia tonsa (Dana) for intensive live feed cultures using an automated Zoolmage system. Aquaculture, v, 422, p. 255-231, 2014. 